\title{
The influence of national culture on the compensation system in selected countries
}

\section{Утицај националне културе на систем компензација у одабраним земљама}

\author{
Dimitrije Gašić \\ University of Novi Sad, Faculty of Economics in Subotica, Subotica, Republic of Serbia, \\ dimitrije.gasic@ef.uns.ac.rs
}

\begin{abstract}
The escalating pace of globalization affects the increased need of organizations to develop effective compensation programs. Business cannot be imagined without one of the key things and that is human resources. Creative and productive employees are of great importance for the success of any organization. For the satisfaction and loyalty of employees, the compensation system, which consists of basic pay, incentive pay, and benefits, is of key importance. The goal of the compensation system is to simultaneously ensure the main goals of employees and employers, i.e. the purchasing power and satisfaction of employees, as well as the business success of the company. In times of crisis, determining the amount of basic pay, selecting adequate incentives, and offering various benefits became especially important. The aim of this paper is to present the basic elements of the compensation system in twenty countries around the world and to analyze the impact of national culture on the compensation system. The paper will present the following dimensions of national culture according to Hofstede's classification: distance from power, individualism versus collectivism, male versus female cultures, avoidance of uncertainty, long-term versus short-term orientation, compliant versus restrained cultures. The analysis included twenty countries around the world, which are grouped as follows: the first 8 countries are members of the EU, the other 6 countries are located in the CEE region and the last 6 countries represent very important countries around the world. The paper determines the influence of the dimensions of national culture on the compensation system in selected countries from the European Union, the region of Central and Eastern Europe, and other countries, the paper is the basis for further research in this area.
\end{abstract}

Keywords: compensations, basic pay, incentives, benefits, national culture.

JEL classification: J31, J33

Сажетак: Ескалирајући темпо глобализације утиче на повећану потребу организација да развију ефикасне програме надокнаде. Пословање се не може замислити без једног од кључних ствари а то су управо људски ресурси. Од великог значаја за успех сваке организације су креативни и продуктивни запослени. За задовољство и оданост запослених од кључне важности представља систем компензација, који се састоји од основне зараде, стимулативне зараде и бенефиције. Циљ система компензације је да истовремено осигурава главне циљеве запослених и послодаваца, односно куповну моћ и задовољство запослених, као и пословни успех компаније. У периодима кризе, утврђивање висине основне зараде, одабир адекватне стимулације и понуда разних бенефиција добија посебан значај. Циљ рада је да представи основне елемената система компензација у двадесет земаља широм света и извршити анализу утицаја националне културе на систем компензација. У раду ће бити приказане следеће димензије националне културе по Хофстеде-овој класификацији: удаљеност од моћи, индивидуализам насупрот колективизму, мушке насупрот зенским културама, избегавање неизвесности, дугорочна насупрот краткорочној оријентацији, попустљиве насупрот уздржаним културама. У анализу је укључено двадесет земаља широм света, које су груписани на следећи начин: првих 8 земаља су чланице ЕУ, других 6 земаља су чланице ЦЕЕ и последњих 6 земаља представљају веома значајне земље широм 
света. У раду је утврђен утицај димензија националне културе на систем компензација у одабраним земаљама из Европске уније, из региона Централно-источне Европе и осталих земаља, рад представља основу за даља истраживања из ове области.

Кључне речи: компензације, основна зарада, стимулације, бенефиције, национална култура.

JEЛ класификација: J31, J33

\section{Introduction}

Human resource management (HRM) is about taking care of people. DeCenzo \& Robbins (2002) state that human resource management is responsible for the human dimension of an organization. Human resource management consists of staffing, development, motivation as well as staff retention. Dessler (2002) points out that modern management puts in the first place the importance of employees as well as the importance of psychological factors such as abilities, motives, goals, expectations etc. He also states that HRM refers to practices and policies necessary to perform managerial tasks relating to personal matters and, in particular, to the recruitment, training, evaluation, and rewarding of employees. Human resource management (HRM) implies the current or previous result or performance of employees, teams, or the entire organization (Slavić et al., 2014).

International Human Resource Management (IHRM) has multiple meanings and definitions by different authors. For instance, according to Taylor et al. (1996), IHRM is a set of different activities, processes, and functions aimed at attracting, developing, and maintaining the human resources of multinational corporations. According to Almond et al., (2004) IHRM deals with identifying and understanding how multinational organizations manage their employees located in different countries around the world to harness human resources in order to achieve local and global competitive advantages. Internationally oriented companies are forced to develop new policies and standards related to employment, training, coaching, and the reward system. It is necessary to continuously harmonize with national legislation, economic and social realities and cultural differences. In relation to national human resource management, IHRM requires a broader view and includes a wider range of activities such as selection, verification of professional competence, obtaining a work permit in foreign countries, cross-cultural adaptation program, helping a couple find a job, etc. (Maksimović, 2014).

Štangl Šusnjar \& Leković (2009) define compensations as a direct financial cost for each company and emphasize that labour costs represent the importance of monetary amounts of total operating costs. In some industries, labour costs can reach as much as $60 \%$ of total operating costs. For this reason, companies should view this cost as an investment that will result in increased company value.

Factors that influence systemic compensation can be external (economic pressures, government policy, and laws, stakeholders, culture, and customs) or organizational (strategic organization, technology, human capital, human resource policies, acceptance, and employee attitudes - fairness and costs), as it is stated by Štangl Šušnjar, Slavić and Berber (2017). 
National culture is an important factor in the compensation system. The most commonly used classification of national cultures is based on Hofstede's research, which distinguishes several main dimensions. The aim of this paper is to present the basic elements of the compensation system in twenty countries around the world and to analyse the impact of the dimensions of national culture on the compensation system.

The paper is structured as follows: the first part contains an overview of the structure of the remuneration system, with special emphasis on the managers' compensation system, compensation management goals, and emphasis on the importance of the remuneration system to employees (their motivation, satisfaction, commitment, etc.). The second part refers to the presentation of the dimensions of national culture according to Hofstede's classification, as well as the tabular presentation of the dimensions of 20 countries around the world. In the third part, the practice of compensation for 20 countries is presented, of which 8 are EU member states, $6 \mathrm{CEE}$ (Central and Eastern European) countries, and 6 countries around the world (Russia, USA, Japan, Switzerland, India, and the UK). This is followed by the fourth part, comprising the analysis of the influence of national culture on the compensation system in selected countries. The paper concludes with conclusions and recommendations for future research.

\section{Theoretical background}

Different authors define the compensation system in different ways. Fay \& Thompson (2001) point out that compensations represent a systemic approach to providing monetary value as well as other benefits to employees in exchange for their work or service and that compensation plays a significant role in attracting high-potential employees as well as retaining existing employees. They also emphasize that the compensation of employees has a great impact on the motivation of all employees to achieve a higher level of performance.

Compensation consists of the basic pay with allowances in the form of various incentives designed at the individual or group organizational level as well as compensation related to tangible and intangible elements for employees (Berber et al., 2017). In this paper, the compensation system is observed so that its main elements are the basic pay with various allowances, incentive pay, which is formed at the individual, group, or organizational level, as well as benefits related to tangible and intangible benefits to workers.

Rewarding employees is considered to be the most complex and sensitive function of human resources management. Through compensation, it influences the motivation of employees to behave and work in a way that affects the achievement of the organization's goals. Based on the observation of the stated goals of the company and employees (expatriates), we conclude that it is very difficult to achieve all goals at the same time and that it is necessary to continuously adjust and balance goals to achieve the strategic goal of the company - survival, maintaining high-level international operations, and growth and development in the long run. In the following section of the paper, the elements of the compensation system will be tabulated (Lowe et al., 2002). 
Table 1: Elements of the compensation system

\begin{tabular}{|c|l|}
\hline Basic pay & $\begin{array}{l}\text { It represents the minimum level of earnings; in some cases, it represents the } \\
\text { standard earnings while in others it is supplemented with other elements of } \\
\text { earnings. }\end{array}$ \\
\hline \multirow{5}{*}{ Incentive pay } & $\begin{array}{l}\text { It refers to rewarding the above-average performance of workers. Companies } \\
\text { can use various methods of individual, group, and organizational stimulation. } \\
\text { Stimulation of individuals usually refers to payment per unit of product, } \\
\text { rewarding innovation, stimulating time savings, and individual bonuses. Group } \\
\text { stimulation takes into account the performance of the whole group rather than } \\
\text { individual members. Incentives at the organizational level reward all employees } \\
\text { for the achieved performance of the organization. }\end{array}$ \\
\hline Benefits & $\begin{array}{l}\text { They represent an indirect part of the compensation system. They refer to } \\
\text { benefits above basic and incentive pays. They mainly include unemployment } \\
\text { insurance, health and pension insurance, company car, food, babysitting, status, } \\
\text { paid transportation costs, counselling services, etc. }\end{array}$ \\
\hline
\end{tabular}

Source: the author, based on Štangl Šušnjar et al. (2017)

\section{Overview of the dimensions of national culture according to Hofstede's classification.}

Compensation professionals in multinational companies need to know the elements of national cultures and their impact on compensation. National culture encompasses common norms, attitudes, and beliefs of individuals within national borders. Hofstede's framework represents the most commonly used national cultural framework in studies such as psychology, sociology, management, or marketing (Soares et al., 2007).

Hofstede used 116,000 questionnaires and over 60,000 respondents in 70 countries in his empirical study (Hofstede, 1984, 1991, 2001, 2005).

Table 2: Overview of the dimensions of national cultures according to Hofstede's classification

\begin{tabular}{|c|l|}
\hline Dimension & \multicolumn{1}{|c|}{ Description } \\
\hline Power distance & $\begin{array}{l}\text { The extent to which society accepts the fact that power in institutions } \\
\text { and organizations is not evenly distributed. }\end{array}$ \\
\hline Uncertainty avoidance & $\begin{array}{l}\text { The degree to which members of society feel uncomfortable due to } \\
\text { uncertainty, ambiguity, something that is far from the status quo. }\end{array}$ \\
\hline $\begin{array}{c}\text { Individualism/ } \\
\text { collectivism }\end{array}$ & The degree to which members of society are integrated into groups. \\
\hline $\begin{array}{c}\text { Masculinity/femininity } \\
\text { Long-term/short-term } \\
\text { orientation }\end{array}$ & $\begin{array}{l}\text { The degree to which members of society strive for achievements, } \\
\text { material rewards, and success, or prefer cooperation, social care, } \\
\text { modesty, and quality of life. }\end{array}$ \\
\hline $\begin{array}{l}\text { Ine degree of inclination that a society has in either short-term } \\
\text { fulfilment of social obligations or long-term orientation towards the } \\
\text { future, persistence, and thrift. }\end{array}$ \\
\hline
\end{tabular}

Source: the author, based on Hofstede \& Minkov (2010); Andrijauskienè \& Dumčiuvienè (2017). 
The following is a tabular presentation of Hofstede's cultural dimensions for selected countries to further analyse the impact of national culture on the compensation system.

Table 3: Overview of the dimensions of the national culture of 20 countries according to Hofstede's classification

\begin{tabular}{|c|c|c|c|c|c|c|c|}
\hline & Country & $\begin{array}{c}\text { Power } \\
\text { distance }\end{array}$ & $\begin{array}{l}\text { Individ } \\
\text { ualism }\end{array}$ & $\begin{array}{c}\text { Masculi } \\
\text { nity }\end{array}$ & $\begin{array}{c}\text { Uncertainty } \\
\text { avoidance }\end{array}$ & $\begin{array}{c}\text { Long term } \\
\text { orientation }\end{array}$ & Indulgence \\
\hline \multirow{8}{*}{ 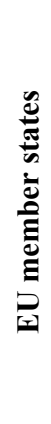 } & Germany & 35 & 67 & 66 & 65 & 83 & 40 \\
\hline & France & 68 & 71 & 43 & 86 & 63 & 48 \\
\hline & Italy & 50 & 76 & 70 & 75 & 61 & 30 \\
\hline & Sweden & 31 & 71 & 5 & 29 & 53 & 78 \\
\hline & Greece & 60 & 35 & 57 & 100 & 45 & 50 \\
\hline & Denmark & 18 & 74 & 16 & 23 & 35 & 70 \\
\hline & Belgium & 65 & 75 & 54 & 94 & 82 & 57 \\
\hline & Netherlands & 38 & 80 & 14 & 53 & 67 & 68 \\
\hline \multirow{6}{*}{ 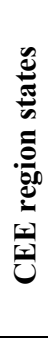 } & Serbia & 86 & 25 & 43 & 92 & 52 & 28 \\
\hline & Hungary & 46 & 80 & 88 & 82 & 58 & 31 \\
\hline & Slovakia & 100 & 52 & 100 & 51 & 77 & 28 \\
\hline & Slovenia & 71 & 27 & 19 & 88 & 49 & 48 \\
\hline & $\begin{array}{c}\text { Czech } \\
\text { Republic }\end{array}$ & 57 & 58 & 57 & 74 & 70 & 29 \\
\hline & Bulgaria & 70 & 30 & 40 & 85 & 69 & 16 \\
\hline \multirow{6}{*}{ 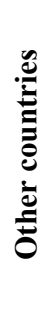 } & Russia & 93 & 39 & 36 & 95 & 81 & 20 \\
\hline & SAD & 40 & 91 & 62 & 46 & 26 & 68 \\
\hline & Japan & 54 & 46 & 95 & 92 & 88 & 42 \\
\hline & Switzerland & 34 & 68 & 70 & 58 & 74 & 66 \\
\hline & India & 77 & 48 & 56 & 40 & 51 & 26 \\
\hline & UK & 35 & 89 & 66 & 35 & 51 & 69 \\
\hline
\end{tabular}

Source: Author based on: https://www.hofstede-insights.com/product/compare-countries/

\section{Overview of compensation systems in selected countries}

"One of the most important factors in every company's business comes out the door every day." People and human resource management are increasingly seen as a key element of competitive advantage (Pfeffer \& Jeffrey, 1998; Gratton et al., 1999; Boxall, 2003). Due to increased competition, globalization, rapid technological change as well as other factors, companies are striving to understand how human resources can be managed to achieve a competitive advantage (Allen \& Wright, 2006). 
In the following section of the paper, a detailed description of HRM compensation practices of $8 \mathrm{EU}$ member states, $6 \mathrm{CEE}$ member states, and 6 countries around the world, which are very important for the analysis, will be presented in a table and performed.

Table 4: Overview of the dimensions of the national culture of 20 countries according to Hofstede's classification

\begin{tabular}{|c|c|c|}
\hline & Country & Compensation system \\
\hline \multirow{6}{*}{ 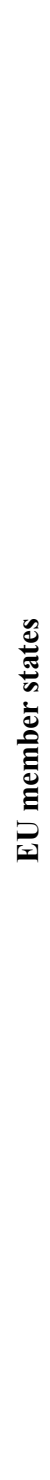 } & Germany & $\begin{array}{l}\text { The legal minimum wage is not set but the introduction for certain industrial } \\
\text { sectors or even general is being discussed. The most important item that } \\
\text { determines the basic pay for all classes are employee performance, relevant } \\
\text { experience and employee classifications. Benefits vary by company size. Some } \\
\text { of the forms of benefits that managers have are a company car (for the elderly } \\
\text { or those who travel frequently), lunch vouchers, life insurance and/or accident } \\
\text { insurance, etc. }\end{array}$ \\
\hline & France & $\begin{array}{l}\text { Basic earnings are defined through a comprehensive collective bargaining } \\
\text { arrangement, with a certain minimum wage. The factor that affects the level of } \\
\text { basic pay of managers and professionals most is qualification. Earnings based } \\
\text { on seniority are used to a lesser extent. One of the common practices is to } \\
\text { allow managers to use cars and other types of benefits in kind (Halima et al., } \\
\text { 2018). }\end{array}$ \\
\hline & Italy & $\begin{array}{l}\text { One of the very important determinants of basic pays at all levels is the } \\
\text { educational level and performance, while the content of the job is very } \\
\text { important for management. There is no minimum wage, but the Italian } \\
\text { constitution guarantees the right to a fair wage. Over the last decade, the } \\
\text { frequency of companies offering different types of securities to their } \\
\text { shareholders, and especially to top management, has increased (Gigliotti, } \\
\text { 2013). Managers generally have high compensation as well as additional } \\
\text { benefits like a company car, low-interest loans, mobile phones, etc. }\end{array}$ \\
\hline & Sweden & $\begin{array}{l}\text { The use of basic pays and bonuses as compensation is rarely applied. An } \\
\text { individual, differential salary system is used concerning a certain level of } \\
\text { employee responsibility, profession, performance as well as market prices. The } \\
\text { minimum wage is not legally defined (Bylander, 2015). When deciding on the } \\
\text { salary for a new employee, the previous salary that the employee had is taken } \\
\text { into account. For managers in senior positions, some incentives such as cars, } \\
\text { accident insurance, life insurance, lunch are used. }\end{array}$ \\
\hline & Greece & $\begin{array}{l}\text { The minimum wage is set for most employees through collective agreements } \\
\text { negotiated annually by the Federation of Greek Industry and the General } \\
\text { Confederation of Greek Labour. Due to the recession, there was a reduced } \\
\text { amount of the minimum wage for young people, and these changes were } \\
\text { implemented in the period } 2009-2017 \text { (Georgiadis et al., 2018). Some of the } \\
\text { benefits enjoyed mostly by senior executives are car, housing, health coverage, } \\
\text { etc. }\end{array}$ \\
\hline & Denmark & $\begin{array}{l}\text { The minimum wage is not legally determined but the collective agreement sets } \\
\text { the minimum wage for a large percentage of the Danish workforce } \\
\text { (Westergaard-Nielsen, 2008). The content of the job is the most important } \\
\text { determinant of basic pays for all levels of the class, as well as performance, } \\
\text { classifications, experience, and seniority. Overtime is not always compensated. } \\
\text { The official car and allowances for additional pensions are mainly intended for }\end{array}$ \\
\hline
\end{tabular}




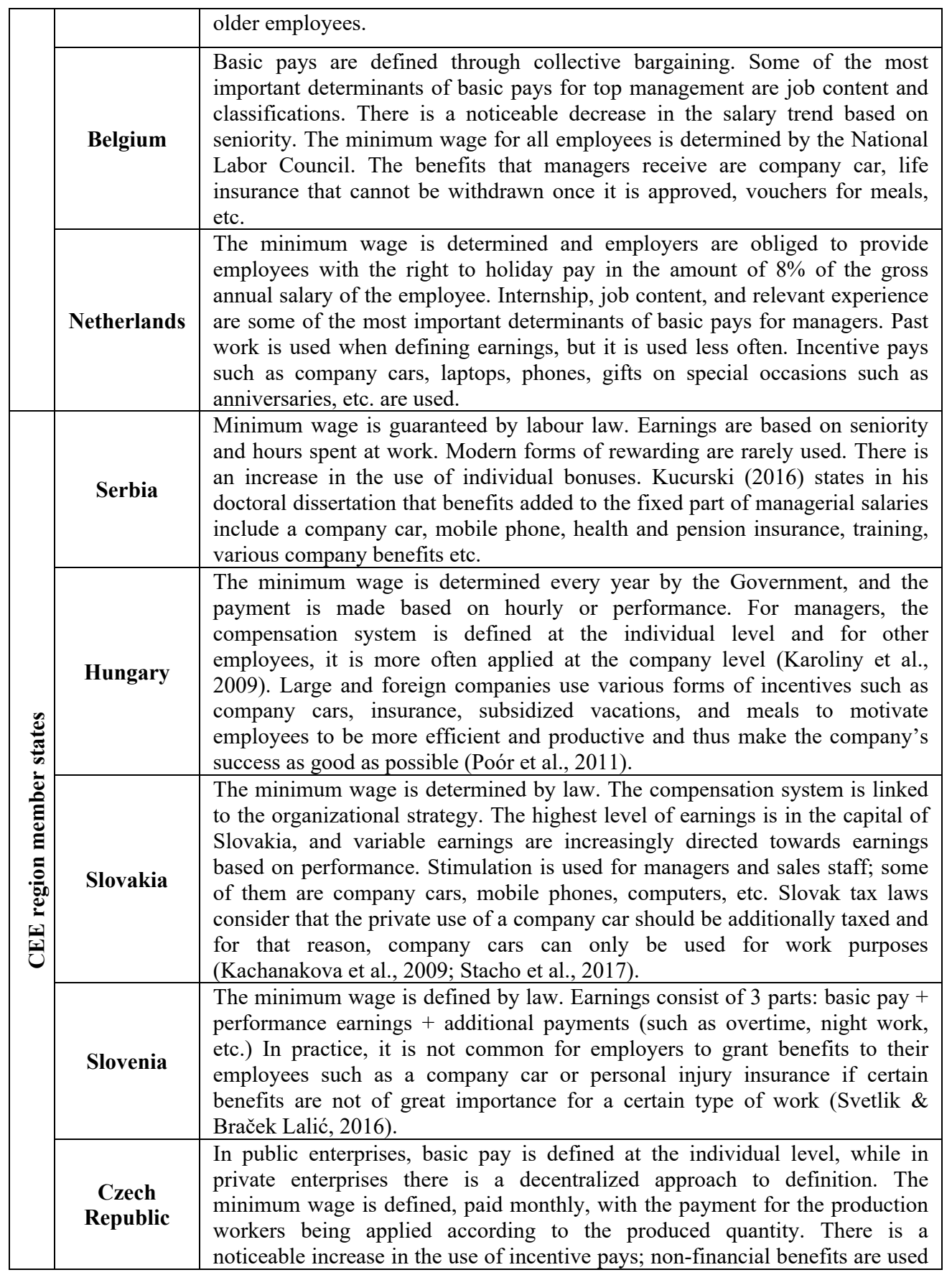




\begin{tabular}{|c|c|c|}
\hline & & $\begin{array}{l}\text { for managers and highly professional staff (Koubek, 2009). Managers during } \\
\text { their employment generally receive a car, computer, mobile phone, and other } \\
\text { benefits for temporary use. These types of benefits are mostly agreed upon by } \\
\text { agreement, and based on that, the method of return should be defined if the } \\
\text { employer proposes the withdrawal of compensation. }\end{array}$ \\
\hline & Bulgaria & $\begin{array}{l}\text { The minimum wage in Bulgaria is defined and collective bargaining is applied. } \\
\text { Non-financial benefits are used to a lesser extent, while incentive pays are most } \\
\text { often used for managers and professional qualities (Morley et al., 2016). } \\
\text { Benefits such as a company car, mobile phone, etc. are not mandatory but they } \\
\text { are generally approved to managers in senior positions. Private insurance } \\
\text { systems and incentive pays are not mandatory in this country (Vatchkova, } \\
\text { 2009). }\end{array}$ \\
\hline \multirow{5}{*}{ 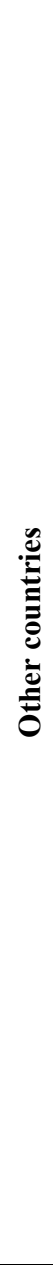 } & Russia & $\begin{array}{l}\text { The basic pay of a manager is determined based on performance, experience, } \\
\text { job content, and seniority. It amounts to } 20 \% \text { of the total figure while } 80 \% \text { are } \\
\text { guaranteed supplements and bonuses (Lukiyanova, 2011). The minimum wage } \\
\text { is legally defined. As for bonuses, there are sectorial guidelines for the } \\
\text { payment of bonuses; for example, in the banking sector as well as for certain } \\
\text { state-owned companies, bonuses depend on the performance of the } \\
\text { organization. Managers of Russian companies participating in private pension } \\
\text { insurance programs have the option of additional pensions (Berber, 2015, p. } \\
\text { 184). }\end{array}$ \\
\hline & SAD & $\begin{array}{l}\text { The minimum wage is defined by law. Wage data analysis is performed to } \\
\text { maintain the development of wage levels within the organization. The } \\
\text { incentive contains an allowance for difficulties when going to another } \\
\text { company located in another state, a departure premium. Standard benefits } \\
\text { include paid leave and protection programs, while enhanced benefits include } \\
\text { expatriate relocation assistance, expatriate children's education allowances, } \\
\text { travel and home allowances, and entertainment allowance (Martocchio, 2004). }\end{array}$ \\
\hline & Japan & $\begin{array}{l}\text { Basic pay is determined by a long salary tradition where employees can expect } \\
\text { an increase in basic pay each year regardless of the performance of the } \\
\text { organization (Whitehill, 1991). Employees in Japanese companies expect their } \\
\text { status to increase due to promotion in the workplace due to long service and } \\
\text { obliging subordinates to treat them with respect and honour. Traditional } \\
\text { Japanese rewarding practices are being replaced by newer, more western forms } \\
\text { such as car, telephone, etc. (Allen et al., 2004). }\end{array}$ \\
\hline & Switzerland & $\begin{array}{l}\text { There is no legal minimum wage in Switzerland, wages based on past work are } \\
\text { less and less in use. The most important determinants of basic pay are the } \\
\text { content of the job, performance, seniority, and experience of the employee. As } \\
\text { for the bonus, it can reach up to } 15 \% \text { of the maximum amount of the } \\
\text { employee's salary. Supervisors may allow the application of individual bonuses } \\
\text { within the budget (Berber, } 2015, \text { p. 184). }\end{array}$ \\
\hline & India & $\begin{array}{l}\text { The basic pay is set at about } 40-50 \% \text { of the fixed fee; the goal is to prevent the } \\
\text { exploitation of labour. Incentives for employees are apartment rental fee, } \\
\text { medical allowance, transportation fee, travel fee, meals etc. Managers receive } \\
\text { various types of compensation for their work, in addition to monetary } \\
\text { incentives, i.e. benefits, and these include pension insurance, life, and health } \\
\text { insurance, and disability (Jaiswall \& Bhattacharyya, 2016). }\end{array}$ \\
\hline
\end{tabular}




\begin{tabular}{|l|l|l|}
\hline UK & $\begin{array}{l}\text { The minimum wage is determined based on the age group of employees. The } \\
\text { most important determinants of basic pay for all grades, with classifications, } \\
\text { performance, job content as well as seniority-based earnings are still used. } \\
\text { Benefits mainly include private health insurance and a car (especially for older } \\
\text { employees). These benefits can be contracted but care must be taken if the } \\
\text { employer proposes to withdraw them (Haque, 2017). }\end{array}$ \\
\hline
\end{tabular}

Source: the author, based on: Berber, 2015;

https://www.sorainen.com/UserFiles/File/Publications/briefing.Employment-benefits-in-the-European-

Union.2007-05-01.Clifford-Chanse-LLP.eng.andisb-agrisr.pdf, https://rewards.aon.com/en-us/

\section{Analysis of the influence of national culture on the compensation system in selected countries.}

This section will analyse the impact of national culture according to Hofstede for selected countries depending on the strength of the dimension; countries with the lowest values (below 35) and those countries with the highest values (above 75).

The dimension "Power distance" refers to the extent to which society accepts the fact that power in institutions and organizations is not evenly distributed. Based on the presented Table 3, we conclude that countries with a large power distance (value above 75) include: Serbia (86), Slovakia (100), Russia (93), and India (77), while countries with a small power distance (value less than 35) include: Germany (35), Sweden (31), Denmark (18), Switzerland (34), and UK (35). In countries with a great power distance, society accepts a hierarchical order in which everyone has a place, while countries with a low power distance want to equalize the distribution of power and demand justification for inequality. The wage system in countries with a great distance from power is similar in selected countries, the minimum wage is legally determined and is generally set depending on the position, length of service, experience of the employee, and incentives and benefits are determined based on success at work. Employees get the opportunity to use a company car, laptop, mobile phone, and other benefits. Regarding employee incentives, there is a small difference between countries, most employees are additionally stimulated through various systems of simulated earnings, but there are also some differences between countries, so for example in Serbia, modern reward systems are not high, in Russia, 80\% of earnings consists of guaranteed extras and bonuses. In contrast to these countries where the minimum wage is defined by law, in countries that have a small distance from power the amount of the minimum wage in most countries is not defined. If the distance from power is observed, in the case of countries with a large power distance, where a hierarchical order is present, there should be a system of rewarding employees for each level at which the employee is to motivate employees from lower levels to more they work and progress to reach a higher hierarchical level where the reward system is at a much higher level. While in countries where power distance is small, countries want to equalize the distribution of power, the proposal is to establish a system of remuneration depending on the work, success, employee, regardless of his position. According to Hofstede (2001), in countries that have a great power distance, there is a tendency towards greater elitism in society. This 
refers to those who are in positions in society will not only be more valued but will be able to extract more wealth. Li \& Harrison (2008) state that in cultures characterized by a great power distance, there are great differences in authority, earnings, and privileges between those in higher and lower positions. On the other hand, in cultures with a small power distance, more consultation on decision-making is noticeable, and less powerful actors are valued and encouraged.

In the dimension "Individualism", the emphasis is on individual rewarding based on the individual performance of employees, based on their performance at work, etc. Based on the presented Table 3, we conclude that individualistic countries (value above 75) include: Italy (76), the Netherlands (80), Hungary (80), the USA (91), and UK (89), while "collectivist" countries (value below 35) where the success of the group is valued more, but also the success of the individual in the group, include: Serbia (25), Slovenia (27) and Bulgaria (30) - CEE members). Based on the information presented in Table 4, we conclude that in countries that belong to individualistic societies, the work and performance of an individual are valued more than a group, which is especially pronounced in countries with a high degree of individualism (the USA and the UK). Opposite them are three countries that are the only members of CEE, which value the success of the group more, but also the additional effort of the individual in the group. It should be noted that the function of a manager who delegates authority and influences groups to direct them towards success is very important. Parker (2001) points out that employers in countries like the USA reward their employees more based on individual success. Research shows that individualism is strongly associated with a country's national wealth and that employees in highly individualistic cultures associate their success with financial status, leading to the strong use of external rewards in recognizing employee success (Gomez-Mejia \& Welbourne, 1991). Conyon \& Schwalbach (1997) showed in their study that the percentage of compensation when comparing 10 European countries was the highest in the UK. A study by Giacobbe-Miller et al., (2003), which compared awarding rewards to 66 American, 113 Chinese, and 87 Russian managers. He concludes that "the USA" and "China" represent cultural opposites in the dimensions of "individualism/collectivism" and "power distance". On the other hand, the authors state that "Russia" shares cultural characteristics with both "China" and the USA, which means that Russia is not expected to differ much from any other country.

Based on Table 3 and the information on the salary system shown in Table 4, an analysis of countries belonging to the "male" cultures (value above 75) was performed: Hungary (88), Slovakia (100), and Japan (95). The characteristic of these societies is the high valuation of perseverance, entrepreneurship, and innovation. This can be confirmed based on the fact that in Japan, Slovakia, and Hungary, employees are additionally stimulated if they achieve a certain result and progress in their business. In contrast, the countries that belong to the "female" culture are Sweden (5), Denmark (16), the Netherlands (14), and Slovenia (19). These countries value social status, quality of life, and stability more. Managers strive for a certain status in society to be more rewarded and thus provide themselves with a better quality of life in society. Sweden has a very small value of "male values", and it is characteristic of this country that the minimum wage is not defined 
by law, an individual differential system is in use. Kluckhohn and Strodtbeck (1961) also point out that female values are dominant in Denmark, Norway, and Sweden, i.e. that they give a high value to the quality of life and care for others. Tosi and Greckhamer (2004) in their paper emphasizes that cultures with a dominance of male values tend to support greater income inequality, while the situation is reversed in cultures where female values dominate. In addition, the same author points out that countries such as Germany, Japan, and the USA tend to have more gender-differential professional structures where certain jobs are fully assigned to women and others to men, while on the other hand in countries like Sweden and Norway work, employee participation and job satisfaction are preferred. Based on the conducted research, he emphasized in his work that he believes that in cultures with a dominance of male values, the material success of an individual is manifested through a greater difference in earnings, while in feminist cultures, social goals are dominant and that relationship is lower.

Analysing the data presented in the paper, we conclude that countries with a "high degree of uncertainty avoidance" (value over 75) that tend to propagate laws, specific rules, procedures include: France (86), Greece (100), Belgium (94), Serbia (92), Slovenia (88), Bulgaria (85), Russia (95) and Japan (92). In contrast, countries with a "low degree of uncertainty avoidance" (values below 35) that accept risk and uncertainty are Sweden (29) and Denmark (23). Based on the presented data, we conclude that most countries with a high degree of uncertainty (such as Serbia and Greece) had a difficult economic period behind them and that it is for these reasons that they want to reduce the risk to the lowest possible level. Minimum wages in countries with a high degree of risk avoidance are defined by law, so this dimension is confirmed, these countries strive for more laws and rules to make the employee wage system fair. In contrast to these countries, the minimum wage in Sweden is not legally defined, which is precisely the characteristic of countries that have a low degree of risk avoidance, there is a lack of law and other specific rules and procedures. Stanojević (2014) emphasized in his paper that when it comes to risk avoidance, some countries limit performance pay to maintain employee predictability and consistency (Japan, Spain, Turkey, etc.). Gerhart (2008) points out that variable wages, incentives, as well as decentralized wage determination, are present mainly in countries with a low degree of uncertainty avoidance, while on the other hand fixed wages (e.g. basic wages), centralized wage determinations and internal equality have a greater role in countries that have a high degree of risk avoidance. Schuler \& Rogovsky (1998) point out that performance-based earnings (especially individual employee performance) are most likely in countries with a low degree of uncertainty avoidance, which is confirmed in the paper to assess individual performance in Denmark and Sweden. As for the distance from power where individual performance is viewed, Denmark and Sweden are among the countries with a small distance from power. Also, the author states that skills-based compensations are more common in countries with a low degree of uncertainty avoidance while length-of-service compensations are probably more prevalent in countries with a high degree of uncertainty avoidance, this is also confirmed in our analysis such as it is the case in Japan, Russia, etc. 
The characteristics of countries that are "long-term oriented" (value over 75) are thrift, sense of shame, etc., based on data from Table 3 of countries that are long-term oriented: Germany (83), Belgium (82), Russia (81) and Japan (88). In contrast, "short-term" countries (below 35) include Denmark (35) and the USA (26). The characteristic of this dimension is protection of the person and personal perseverance as well as the fulfilment of social obligations. One of the specifics of this analysis is Japan, where there is a plan for the system of salaries and remuneration of employees in accordance with years of service, while in the USA, which is short-term oriented, employees are rewarded based on performance, and the goal is to achieve more today.

Based on the above Table 3, we come to the conclusion that of the analysed countries, the country that belongs to the "indulgence" category in national culture (over 75 ) is Sweden (78) and it is characterized by the enjoyment of life and entertainment while in countries that belong to "restraint" category by national culture are Italy (30), Serbia (28), Slovakia (28), Czech Republic (29), Bulgaria (16), Russia (20) and India (26), characterized by control of meeting needs based on strict social norms. What differs significantly in Sweden from other countries is that the basic pay and bonuses are less used, the minimum salary is not legally defined, while in the countries that are abstained it is not the situation, where the minimum salary is determined by law.

\section{Conclusion}

Based on the conducted research on the influence of national culture on the compensation system in selected countries, we conclude that in all six dimensions of national culture according to Hofstede's classification there are different influences between selected countries. When comparing the wage system between countries with large and small power distances, it was found that in countries with large power distances, the wage system is similar, the minimum wage is legally determined and is generally set depending on the position, seniority, and experience of the employee, while in countries with a small power distance, the minimum wage is not defined by law. If the distance from power is observed, in the case of countries with great power distance, there is a hierarchical order and a system of rewarding employees for each level, where the employer is to motivate employees from lower levels to work harder and they progress to reach a higher hierarchical level, where the reward system is at a much higher level. On the other hand, in countries where the power distance small, countries want to equalize the distribution of power, the reward system is established depending on the work, success, employee, regardless of position. A comparison of countries based on whether they are more individualistic or collectivist confirms the conclusion that in individualistic cultures (for example Italy, the Netherlands, Hungary, the USA, and the UK) the performance of an individual is more valued than the performance of a group as in collectivist countries such as Serbia, Slovenia, and Bulgaria. When comparing "men" against "women" cultures, employees are additionally stimulated for success and they value innovation and perseverance more. In "women's" cultures, the status and quality of life are more valued. These cultures include countries such as Denmark, the Netherlands, Slovenia, and Sweden. By comparing the countries, it was established that Sweden has a very small value of "male" values, and it is characteristic of 
this country that the minimum wage is not defined by law, and an individual differential system is in use. Comparing countries based on the "avoidance of uncertainty" dimension, differences between countries with a high and low degree of avoidance of uncertainty are noticeable. In the case of countries with a high degree of uncertainty avoidance (for example France, Greece, Belgium, Serbia, Slovenia, Bulgaria, Russia, and Japan) the determination of the minimum wage is defined by law and this is one of the characteristics of countries with a high level of uncertainty avoidance, characterised by laws, specific rules, procedures, etc. In contrast, in countries with a low degree of uncertainty avoidance (for example, Sweden and Denmark), the minimum wage is not legally defined in the observed countries. When comparing countries that are long-term oriented versus those that are short-term oriented, a different impact on the compensation system is noticeable, and the two countries stand out. One of the specifics of this analysis is Japan, where there is a plan regarding the system of salaries and remuneration of employees in accordance with years of service, this country is known for planning everything for a longer period, so in accordance with the compensation system in the long run. While this is not the situation in the USA: this country is short-term oriented, employees are rewarded based on performance, more effort and success of the individual is seen. As stated, this country belongs to the individualistic culture and thus confirms this thesis that individual performance is more valued. Based on the comparison of countries based on the last dimension according to Hofstede, indulgence/restraint, it is noticeable that in Sweden, which belongs to indulgent cultures where enjoyment of life is seen more than savings, the minimum wage is not legally defined and bonuses are less used. On the other hand, we have the example of countries like Serbia, which belongs to the restrained culture, which is characterized by the control of meeting needs based on social norms, less spending, no emphasis on free time. In general, all CEE member countries have shown restraint. The dimensions of national culture affect the compensation system in selected countries and there are significant differences in the elements of the wage system in the observed countries, which is partly explained by differences in the dimensions of national culture.

All human resource managers, especially those working in multinational companies, should be aware of the different dimensions of national culture on the compensation system as well as the specifics of the basic pay system, incentives, and benefits of different countries to create a compensation package that will contribute to employee satisfaction.

Limitation of the research lies in the fact that the available non-standardized secondary data on HRM practice were used. Future directions of research can be seen in deeper analysis based on empirical research on specific practice in selected countries, on a representative sample. In the research, the researchers should determine the indicators of economic development such as GDI per capita, FDI per capita, unemployment rate, average wages of employees, etc. 


\section{References}

Allen, M. R., \& Wright, P. M. 2007. Strategic management and HRM. In P. F. Boxall, J. Purcell, \& P. M. Wright (Eds.), The Oxford handbook of human resource management (p. 88-107). Oxford: Oxford University Press. http://dx.doi.org/10.1093/oxfordhb/9780199547029.003.0005

Allen, R. S., Takeda, M. B., White, C. S., \& Helms, M. M. (2004). Rewards and organizational performance in Japan and the United States: a comparison. Compensation \& Benefits Review, 36(1), 7-14. Doi: https://doi.org/10.1177\%2F0886368703261401

Almond, P., Clark, I., \& Tregaskis, O. (2004). HRM in multinationals: a comparative international perspective. In I. Beardwell, L. Holden, \& T. Claydon (Eds.), Human Resource Management: A Contemporary Approach (p. 587-636). Harlow: Prentice-Hall.

Andrijauskienė, M., \& Dumčiuvienė, D. (2017). Hofstede's cultural dimensions and national innovation level. In DIEM: Dubrovnik International Economic Meeting, 3(1), 189205.

Berber, N. (2015). Komparacija upravljanja kompenzacijama u Republici Srbiji i zemljama Evrope. Doktorska disertacija. Subotica: Ekonomski fakultet u Subotici.

Berber, N., Morley, M. J., Slavić, A., \& Poór, J. (2017). Management compensation systems in Central and Eastern Europe: a comparative analysis. The International Journal of Human Resource Management, 28(12), 1661-1689. Doi: https://doi.org/10.1080/09585192.2016.1277364

Boxall, P. (2003). HR strategy and competitive advantage in the service sector. Human Resource Management Journal, 13(3), 5-20. Doi: https://doi.org/10.1111/j.17488583.2003.tb00095.x

Bylander, E. (2015). Evidence in civil law-Sweden. Institute for Local Self-Government and Public Procurement Maribor. Doi: https://doi.org/10.4335/978-961-6842-60-0

Conyon, M. J., \& Schwalbach, J. (1997). European differences in executive pay and corporate governance. Humboldt-Universität zu Berlin. 97-114 Doi: https://doi.org/10.18452/9360

Decenzo D.A., \& Robbins S.P. (2002). Human Resource Management, $7^{\text {th }}$ edition. Danvers: John Wiley \& Sons.

Dessler, G. (2002). Framework of Human Resource Management, $2^{\text {nd }}$ edition. New Jersey: The Dryden Press, Prentice Hall.

Fay, C. H., \& Thompson, M. A. (2001). Contextual determinants of reward systems' success: An exploratory study. Human Resource Management, 40(3), 213-226. Doi: https://doi.org/10.1002/hrm.1012 
Georgiadis, A., Kaplanis, I., \& Monastiriotis, V. (2018). The impact of minimum wages on wages and employment: evidence from Greece. GreeSE Paper 131. London: Hellenic Observatory, LSE.

Gerhart, B. (2008). Compensation and national culture. In L.R. Gomez-Mejia and S. Werner (Eds.), Global compensation: Foundations and perspectives (p. 142-57). London: Rutledge.

Giacobbe-Miller, J.K., Miller, D.J., Zhang, W., \& Victorov, V.I. (2003). Country and organization-level adaptation to foreign workplace ideologies: A comparative study of distributive justice values in China, Russia and the United States. Journal of International Business Studies, 34, 389-406. Doi: https://doi.org/10.1057/palgrave.jibs.8400040

Gigliotti, M. (2013). The compensation of top managers and the performance of Italian firms. The International Journal of Human Resource Management, 24(4), 889-903. Doi: https://doi.org/10.1080/09585192.2012.702317

Gomez-Mejia, L. R., \& Welbourne, T. (1991). Compensation strategies in a global context. Human Resource Planning, 14(1), 29-41.

Gratton, L., Hope Hailey, V., Stiles, P., \& Truss, C. (1999). Strategic Human Resource Management: Corporate Rhetoric and Human Reality. Oxford University Press. Doi: https://doi.org/10.1093/acprof:oso/9780198782049.001.0001

Halima, M. A. B., Koubi, M., \& Regaert, C. (2018). The effects of the complementary compensation on sickness absence: an approach based on collective bargaining agreements in France. Labour, 32(3), 353-394. Doi: https://doi.org/10.1111/labr.12123

Haque, F. (2017). The effects of board characteristics and sustainable compensation policy on carbon performance of UK firms. The British Accounting Review, 49(3), 347-364. Doi: https://doi.org/10.1016/j.bar.2017.01.001

Hofstede G. (1984). Culture's consequences: international differences in work-related values. Newbury Park, $C A$ : Sage Publications.

Hofstede, G. (1991). Cultures and organizations: Software of the mind (London and New York, McGraw hill). House, RJ, Hanges, PJ, Javidan, M., Dorfman, PW, \& Gupta, V. (Eds. 2004), Airaksinen, 1-25.

Hofstede, G. (2001). Culture's consequences: Comparing values, behaviors, institutions and organizations across nations. London, New Delhi: Sage Publications.

Hofstede, G., Hofstede, G. J., \& Minkov, M. (2005). Cultures and organizations: Software of the mind (Vol. 2). New York: Mcgraw-Hill.

Hofstede, G., \& Minkov, M. (2010). Long-versus short-term orientation: new perspectives. Asia Pacific Business Review, 16(4), 493-504, Doi: https://doi.org/13602381003637609 
Jaiswall, S. S. K., \& Bhattacharyya, A. K. (2016). Corporate governance and CEO compensation in Indian firms. Journal of Contemporary Accounting \& Economics, 12(2), 159-175. Doi: https://doi.org/10.1016/j.jcae.2016.06.001

Kachanakova, A., Nachtmannova, O., Janiakova, Z., Roby, Z., Zubrikova, D., \& Blstakova, J. (2009). Managing human resources in Slovakia. In M. J. Morley, N. Heraty, \& S. Michailova (Eds.), Managing Human Resources in Central and Eastern Europe (p. 158187). Oxon: Routledge

Karoliny, Z., Farkas, F., \& Poór, J. (2009). In focus: Hungarian and Central Eastern European characteristics of human resource management - an international comparative survey. Journal of East European Management Studies, 14(1), 9-47. Doi: https://doi.org/10.5771/0949-6181-2009-1-9

Kluckhohn, F. R., \& Strodtbeck, F. L. (1961). Variations in value orientations. Row, Peterson.

Koubek, J. (2009). Managing Human Resource in the Czech Republic. In M. Morley, N. Heraty, \& S. Michailova. (2009). Managing Human Resources in Central and Eastern Europe (p. 132-157). London and New York: Routledge.

Kucurski, M. (2016). Uticaj modela nagrađivanja menadžera i zaposlenih na performanse organizacija u Srbiji. Doktorska disertacija. Beograd: Univerzutet Singidunum.

Li, J., \& Harrison, J. R. (2008). National culture and the composition and leadership structure of boards of directors. Corporate Governance: An International Review, 16(5), 375-385. Doi: https://doi.org/10.1111/j.1467-8683.2008.00697.x

Lowe, K. B., Milliman, J., De Cieri, H., \& Dowling, P. J. (2002). International compensation practices: a ten-country comparative analysis. Human Resource Management, 41(1), 45-66. Doi: https://doi.org/10.1002/hrm.10019

Lukiyanova, A. (2011). Effects of minimum wages on the Russian wage distribution. Higher School of Economics Research Paper No. WP BRP 9. Doi: https://dx.doi.org/10.2139/ssrn.2002938

Maksimović, V. (2014). International aspect of human resource management: Case study: company 'Rapp Marine Group' in Serbia. Ekonomski signali, 9(2), 63-83. Doi: https://doi.org/10.5937/ekonsig1402063M

Martocchio, J. J. (2004). Strategic compensation: a human resource management approach. Pearson Education India.

Morley, M. J., Heraty, N., \& Michailova, S. (Eds.). (2016). Managing human resources in Central and Eastern Europe. London: Routledge.

Parker, G. (2001). Establishing remuneration practices across culturally diverse environments. Compensation \& Benefits Management, 17(2), 23-23. 
Pfeffer, J., \& Jeffrey, P. (1998). The human equation: Building profits by putting people first. Boston: Harvard Business Press.

Poór, J., Karoliny, Z., Alas, R., \& Vatchkova, E. (2011). Comparative international human resource management (CIHRM) in the light of the Cranet regional research survey in transitional economies. Employee Relations, 33, 428-443. Doi: https://doi.org/10.1108/01425451111142710

Schuler, R. S., \& Rogovsky, N. (1998). Understanding compensation practice variations across firms: The impact of national culture. Journal of International business studies, 29(1), 159-177. Doi: https://doi.org/10.1057/palgrave.jibs.8490030

Slavić, A., Berber, N., \& Leković, B. (2014). Performance management in international human resource management. Serbian Journal of Management, 9(1), 45-58. Doi: https://doi.org/10.5937/sjm9-4678

Soares, A. M., Farhangmehr, M., \& Shoham, A. (2007). Hofstede's dimensions of culture in international marketing studies. Journal of Business Research, 60(3), 277 284. Doi: https://doi.org/10.1016/j.jbusres.2006.10.018

Stacho, Z., Stachová, K., Hudáková, M., \& Stasiak-Betlejewska, R. (2017). Employee adaptation as key activity in human resource management upon implementing and maintaining desired organisational culture. Serbian Journal of Management, 12(2), 303313. Doi: https://doi.org/10.5937/sjm12-10340

Stanojević, M. D. (2014) Kompenzacije u međunarodnom menadžmentu ljudskih resursa. Svarog, 9, 180-193.

Svetlik, I., \& Braček Lalić, A. (2016). The impact of the internationalisation of higher education on academic staff development-the case of Slovenian public universities. Studies in Higher Education, 41(2), 364-380. Doi: https://doi.org/10.1080/03075079.2014.942266

Štangl Šusnjar, G., \& Leković, B. (2009). Performance-based pay in human resources development. Strategic Management, 14, 1-14.

Štangl Šušnjar, G., Slavić, A. \& Berber, N. (2017). Menadžment ljudskih resursa. Subotica: Ekonomski fakultet u Subotici.

Taylor, S., Beechler, S. \& Napier, N. (1996). Toward an integrative model of strategic international human resource management. Academy of Management Review, 21(4), 959985. Doi: https://doi.org/10.5465/amr.1996.9704071860

Tosi, H. L., \& Greckhamer, T. (2004). Culture and CEO compensation. Organization Science, 15(6), 657-670. Doi: https://doi.org/10.1287/orsc.1040.0099

Vatchkova, E. (2009). Managing human resources in Bulgaria. In M. J. Morley, N. Heraty, \& S. Michailova (Eds.), Managing human resources in Central and Eastern Europe (p. 243277). Oxon: Routledge 
Westergaard-Nielsen, N. (Ed.). (2008). Low-wage work in Denmark. New York: Russell Sage Foundation.

Whitehill, A. M. (1991). Japanese management: Tradition and transition. London: Routledge.

Clifford Chance. (2007, May). Employment and Benefits in the European Union. Retrieved May 17, from https://www.sorainen.com/UserFiles/File/Publications/briefing.Employmentbenefits-in-the-European-Union.2007-05-01.Clifford-Chanse-LLP.eng.andisb-agrisr.pdf

Hofstede insights (2021). Retrieved: April 3, 2021 from https://www.hofstedeinsights.com/product/compare-countries/.

Rewards Solutions (2021). Retrieved: April 3, 2021 from https://rewards.aon.com/en-us/ 